\title{
The Problems of Qualification of Illegal Alienation of Ownership of Residential Premises
}

\author{
Darkhan Shynybekovich Kussainov ${ }^{1}$ \\ ${ }^{1}$ Karaganda Academy of the MIA of the Republic of Kazakhstan named after Barimbek Beisenov, Kazakhstan \\ Correspondence: Darkhan Shynybekovich Kussainov, Ermekov Street, 124, Karaganda, 100021, Kazakhstan.
}

Received: October 25, 2014 Accepted: November 25, 2014 Online Published: March 20, 2015

doi:10.5539/ass.v11n8p188 URL: http://dx.doi.org/10.5539/ass.v11n8p188

\begin{abstract}
This article discusses the importance of proper classification of crimes in law enforcement. Proper assessment of criminal law offenses, with signs of criminal offenses by authorized entities is of particular importance in the modern period. With regard to the subject matter it should be noted that a number of different types of problems of qualification fraud in residential real estate, as well as problems of differentiation of responsibility for that act. Acquisition and alienation of real estate is an important and crucial moment in the life of every person, often because for many it is the only value. Because of the high cost of real estate around there are different kinds of intermediaries, criminal organizations, dissemination of fraud in this area. In this article we will talk about fraud in the criminal law sense, which is often difficult to prove. Practice shows that the wrong behavior of the victims of the real estate market and relevant state bodies, their faulty actions often substantially predetermines tragic consequences.
\end{abstract}

Keywords: fraud, property, theft, qualifications, living space, housing, alienation of property rights, theft of property, illegal acquisition

\section{Introduction}

In modern criminal law of Kazakhstan Republic the property is recognized as one of the most important legally protected objects. Protection of property against crime is one of the tasks of the Criminal Code of the Republic of Kazakhstan set out in part 1 of Clause 2. Note that in the list of social benefits, interests and values placed under the protection of the Criminal Code of the Republic of Kazakhstan, the property is in second place - after the rights, freedoms and legitimate interests of citizens, the most important legally protected objects (Begaliyev, 2009, p. 61). The current legislation provides the legal system of the country in accordance with the Constitution of the Republic of Kazakhstan. It requires further development - phase improvement, adoption, if necessary, new regulations to meet the requirements of the further democratization of society and the problems of its socio-economic development (Begaliyev, 2009, p. 105). The lack of a close relationship between the scientific world and the practice gives rise to, the difficulties in law enforcement on the one hand, on the other - a false idea of objective reality in the scientific world. In this regard, "vicious" practice dictates the rules expressed in the diversity of interpretations of the same law, depending on the regions and units of government. For anybody not a secret (especially for practitioners of the internal Affairs bodies), that the understanding and interpretation of the same provisions of the law may differ, for example, prosecutors and bodies of preliminary investigation, not to mention the judiciary. Due to the lack of uniform understanding, often there are disputes between government agencies, which often arise in mutual misunderstanding, and in some cases conflict.

\section{Method}

At all times the development of the law on criminal responsibility for crimes against property, theft was the most common act in the system of property crime, traditionally occupying the first place, and which is the "standard" form of theft. As a result of the theft, the owner of a property owner deprived of property under their ownership or possession, and thus it is caused by damage to property. And on the other hand, a person who secretly acquiring other people's property illegally, i.e. contrary to the established order in the state distribution of wealth , enriched by an amount equal to the value of the property ( Borchashvili \& Mukhashev, 2009, p. 100).

The objective side of the analyzed acts is expressed in action. The defining characteristic of theft as a form of theft, is a secret way of committing a crime (Kuznetsova, 2002). 
In the legal literature, researchers have expressed different views on the secret nature of the theft. Some authors recognize secret is theft, which is not conscious victim (Isaev, 1938; Grishaev, 1967). Others add that the guilty person should be convinced that there is a secret (the Commentary to the criminal code of the RSFSR, 1971). Third is considered as theft is theft, which would not confess the victim and his guard (Yakubovich, 1962, p. 10).

Criminal law, in turn, did not say what is meant by secret theft. This is evidenced by the Supreme Court of the Republic of Kazakhstan in claim 4 normative resolution "On judicial practice in cases of theft" that when deciding whether the theft of secret courts must proceed from the perception of themselves guilty. If the offender believes that operates imperceptibly, the theft should be classified as theft, even if the owner or other person observes his actions (Normative resolution of the Supreme Court of the Republic of Kazakhstan, 2003). In determining the nature of the secret theft should first clarify the intent of the guilty, i.e. subjective perception of the theft. To recognize the existence of theft requires that the perpetrator tried to commit theft of secret and it was part of the intent is the secrecy of the appropriation of another's property.

According to doctor of legal Sciences, Professor I. Sh. Borchashvili, for qualifying a secret theft requires the seizure occurred unnoticed not only for the owner of the things, but also for protecting this property, as well as to third parties. All of them are either absent at the time of committing theft, or being present at the crime scene, not aware of the criminal nature committed by the guilty actions (Borchashvili \& Mukashev, 2009, p. 106).

This proposition follows from the provisions of paragraph 4 of the Regulatory resolution of the Supreme Court of the Republic of Kazakhstan "On judicial practice in cases of theft, it stated that "Theft should be classified as theft and in cases where any of the above persons sees the event of an acquisition of property, but not aware of his criminal nature" (Normative resolution of the Supreme Court of the Republic of Kazakhstan, 2003, item.4).

In the case when the perpetrator is not aware that the criminal nature of his actions became known, committed embezzlement remains theft, because the thief continues to operate with the conviction, in the secrecy of his crimes. For the recognition of the embezzlement secret, if it is done in the presence of eyewitnesses, is required to establish that these people were not aware of the criminal nature committed wrongful acts (Borchashvili \& Mukhashev, 2009, p. 107).

On the subjective side of the theft committed with direct intent and purposes of gain, i.e. the offender is aware of the social danger of his actions, anticipating the possibility or inevitability of socially dangerous consequences (Borchashvili \& Mukhashev, 2009, p. 113). Mercenary purpose the theft, as with any other form of embezzlement, expressed in a desire to enrich the person himself or to enrich others at the expense of another's property without complying with the distribution of wealth, established by the legislation.

Thus, embezzlement is a secret, if committed:

1) In the absence of anyone else;

2) In the presence of the victim or other persons, but unnoticed to them;

3) In the presence of such persons, observing seizure of property, but do not understand the nature of the acts committed and the value of what is happening;

4) In the presence of any persons watching the offender, understand and correctly assess their character, but does not reveal itself, so that the offender remains in the belief that he is acting in secret;

5) In the presence of any persons watching the offender, understand and properly evaluate them and does not hide his crime, but who are not strangers to the offender, in the sense that would allow to talk about the openness of its actions (Borchashvili \& Mukhashev, 2009, p. 105).

Consider these facts on the example of specific criminal cases. During the study of the materials of the criminal case initiated on the falsification of documents of title to an apartment at Karaganda city Staleliteynaya Street 3/3a.42 flat, from the interview of the victim citizen Z. M. Yu. It was found that he bought the apartment in 2001 for mother-in-law citizen M.A., who lived in it, alone, because the victim himself and his family lived in Astana. Since 2004, after the death of citizen M.A this apartment has been empty. Later, in 2006, citizen Z. M. Yu had come to Karaganda to check the condition of the apartment but found that the previously installed wooden door has been replaced with new metal with the new set of locks, keys, which he hadn't. However, the victim, Z. M. Yu didn't sell this apartment to anyone and didn't provide. Later, in the course of a criminal investigation, it was found that the criminals who forged power of attorney on behalf of the victim. Z. M. Yu. The right to implement the above apartment, tried to sell it to citizen. O. Zh. T. (The materials of the criminal case \# 08351303100840 , 2010).

A similar situation has been established in the study of the materials of the criminal case initiated on the fact of 
illegal alienation of ownership of the apartment in Karaganda city Tattimbeta Street 8 flat 4 . During the interrogation of the victim citizen. O. Z. M. explained that since 1991 was the owner of this apartment, but the last few years lived at a different address, and for this reason a long time apartment was empty. As a result, in 2007, at the next visit to the apartment owner citizen. O. Z. M. discovered the strangers renovating the apartment. In this incident, it was stated to the law enforcement and as a result of the investigation of the criminal case, it was found that the above flat on vehicle title document forgery, namely archival reference the purchase contract between the owner citizen O. Z. M. and front man citizen. B. A. A., was implemented to third parties who subsequently decided to make renovation in the bought apartment (materials of the criminal case \# 09351003100074, 2009).

In addition, we would like to use as an example a case related to illegal disposal of ownership of the apartment located in Karaganda district 17 h.39 flat 67. During the investigation of the criminal case initiated on this fact, it was found that the victim citizen D.G.K. lived at the address with his family since 2000 pursuant to a warrant issued by the district akimat (administration). In February 2008, the latter was called to the court upon the eviction of her and her family out of this apartment, as appropriate suit was filed by citizen T. E. D., who claimed that he had purchased this apartment in the contract of sale. However, the complainant stated that the apartment was not sold to anyone, that she is not going to sell and any documents related to the disposition of the flat were not designed by her. As a result of relevant expertise, it was found that this apartment was implemented grad on false documents (materials of the criminal case \#10351003100126, 2010).

Thus, the study of the above and a number of other criminal cases involving wrongful alienation of property rights to residential premises, it was found that the apartment owners were not aware of having committed a crime against them and did not even know about the plunder of their property. Obviously, that these are signs of secret plunder of property.

The question arises - whether plunder ownership of the apartment be considered as theft, with appropriate signs. But personal experience does not allow to bring an example of a single case in practice in any criminal case, where the object of the crime was flat, was qualified under clause 175 of the criminal code of the Republic of Kazakhstan - the theft. It can be concluded that the judicial and investigative practice, the circumstances of the issue are not always taken into account and, in most cases, may lead, in our view, an incorrect definition of the offense.

\section{Results}

The next important part against property is a fraud. Analysis of judicial and investigative practice in cases of fraud shows that in the classification of the crime there are some difficulties. They are most often associated with signs of misunderstanding not only objective, but also subjective side of fraud. In this regard, it is necessary to define the concept of fraud, deceit and abuse of trust, methods, material elements of fraud (Begaliyev, 2009, p. 4). Material harm from the perpetration fraud has a significant share of the total volume of the damage caused by all kinds of crimes against property (Begaliyev, 2009, p. 8).

Public danger of fraud is that it violates public relations property regardless of its form, related to the procedure of distribution of wealth, established in the state, about not only the property but also property rights. Due to fraud, on the one hand, the owner or another owner's property or rights to property lose this property or right to property that entails causing them damage to property, and the person acquiring the property or right to property by way of deception or abuse of trust illegally, i.e. addition and contrary to the established national procedures distribution of wealth, is enriched in an amount equal to the value of the property or has an opportunity of enriching themselves at the expense of the right to property in the appropriate amount (Borchashvili \& Mukashev, 2009).

The legislation defines fraud as plunder of another's property or the acquisition of rights by deception or abuse of trust. Fraud as a form of plunder has all the signs of plunder and at the same time contains features that are not inherent in the General concept of plunder, some of its forms.

Fraud encompasses two separate offences:

a) Fraudulent misappropriation of another's property;

b) Fraudulent acquisition of another's property. (Volzhenkin, 1998 p. 36).

It can be concluded that fraud is a generic having two different ways of crime: plunder of another's property or the acquisition of another's property by deception and abuse of trust. There are some common signs - it is an object, the method and the subject of wine. The difference can be lit in the characterization of the object and the objective side. In addition, under current law, the theft does not provide for the possibility of plunder of property rights. 
On this issue I. Sh. Borchashvili has a different opinion. He argues that the object of the crime is property right. The subject of the analyzed crime is someone's property. However, fraud may be not only the property but the right to it (Borchashvili \& Mukashev, 2009, p. 195).

According to Borchashvili I. S. documents giving the right to receive property, including money, can be subject to fraud. These include documents that contain certain property rights, and to implement this right can only be subject to the presentation of such a document. The acquisition of such securities is equivalent to the acquisition by material values. With regard to the legal nature of the property, the subject of fraud may be property or right to property not owned by the perpetrator of the right of ownership. The latter is not valid, not alleged right to dispose of that property as their own, as this property belongs by right of ownership to another person (Borchashvili \& Mukashev, 2009, p. 195).

Borchashvili I. Sh, in turn identifies four ways to commit fraud:

1) Plunder of property by deception;

2) Plunder of property through abuse of trust;

3) Purchase rights on another's property by deception;

4) Purchase rights on another's property through abuse of trust (Borchashvili \& Mukashev, 2009, p. 196).

Deception in the fraud can be expressed in deliberate false statement is certainly not existing or concealment, which the circumstances of the case had to be reported to the owner or to the owner of the property. Deception when fraud can be both oral and written. Use with the theft of forged documents is a form of deception and these actions are additional qualifications by part three of clause 325 of the criminal code of KR do not require. When fraud by abuse of confidence guilty using a trust relationship between him and the owner or other lawful owner of the property, makes deception or misleading (Normative Resolution of the Supreme Court of the Republic of Kazakhstan, 2003, item 19).

In his dictionary S. I. Ozhegov says that fraud is "a false representation of something, the delusion" (Ozhegov, 1990, s428). To cheat means to mislead, to act unfair towards someone... to break the promise" (Ozhegov 1990, s428).

Deception can take the active form or to be expressed in the passive behavior. Active deception is the deliberate misrepresentation of the owner or any other owner of property by means of false information, providing false documents and other actions that create a misconception about the reason of the transfer of property in the possession of the perpetrator and causing him the illusion of legality of the transfer. Passive deception lies in the failure to communicate to the victim information about the circumstances, knowledge of which kept would last from disposal of property (Borchashvili \& Mukashev, 2009, p. 197).

It should be noted that when the plunder perpetrated by fraud, false information on certain circumstances which give the right to receive the property, not just reported, and confirmed by deceitful means to ensure that mislead the person in possession or charge of the property, and to convince him of the need to transfer this property to the perpetrator (Borchashvili \& Mukashev, 2009, p. 198).

Any deception should be considered fraudulent if it is intended to incite the victim to the desire or consent to transfer fraudster property or right to property (Borchashvili \& Mukashev, 2009, s199).

In this case, a prerequisite for consideration of fraud is that deception acts as a way to influence the consciousness of the victim, a means of suggestion, persuasion, which the disposition of the property is carried out by it under the law or other legal acts in his own interest (Borchashvili \& Mukhashev, 2009, p. 200).

In our opinion, we should agree with the scholars that the deception and abuse of trust as a means of committing fraud are linked so closely that hold between them a clear distinction is not always possible. Abuse often occurs in combination with fraud. Usually a person seeks, first, to win the trust of the victim to make it easier to commit fraud. Deception in many cases would be impossible if the victim did not feel a certain confidence in the deceiver. Due to the fact that deception is used by the offender not only to induce the victim to transfer the property, but in order to ingratiate himself with the victim, to gain his trust, such deception at the same time looks like a breach of trust. Therefore, we consider it reasonable opinion of lawyers that breach of trust is a specific type of deceit (fraud trust) and "therefore close contact with the deception" (Borzenkov, 1971, p. 75; Vladimirov \& Lyapunova, 1983, p. 99).

According to Ozhegova SR - confidence is the "Certainty in someone's honesty, sincerity, the correctness of something" (Ozhegov, 1990, p. 173). A. V., Arendarenko and I. I. Golubov believe that: ".... the abuse of trust is a prerequisite for committing fraud, but the condition is necessary since it is difficult to imagine the fraud without 
trust" (Arendarenko \& Golubov, 2002, p. 58).

However, B. V. Petuhov does not agree with this view. This position author substantiates that, firstly, breach of trust, in its essence, is a means of misleading the role of this tool performs only the deception, second, the opinion and contrary to the legislative definition of fraud, dealing with fraud and breach of trust as an independent means of committing crimes (Petukhov, 2004, p. 63).

Abuse of trust as part of the fraud, says I. Kolesov, acts as a way of taking possession of the property, and when the attacks on private property - and also as a way of acquiring the right property or other property benefits (Kolesov, 1992, p. 67).

\section{Discussion}

In this situation, the author's position is the following, it is necessary to amend the current legislation on the above items discriminating between each other two elements of crime. When stolen property taken from the victim against his will and secretly from him, while at the fraud the owner or legal owner transfers property to the offender being the misguided as a result of deception or abuse of trust. Analysis of criminal cases showed that the alienation of ownership of residential premises was carried out against the will of the rightful owners. Moreover, the victims in most cases were not in contact with the criminals.

Penal law at 175 clause of the current criminal code of 16 July 1997 have clearly defined the responsibility of the secret plunder of another's property without providing an alternative to the criminal liability for illegal secret acquisition of the rights to it. The author's opinion is inclined to think that this provision does not allow in practice, with clear signs of secrecy wrongful acts against the guilty parties under clause 175 of the criminal code of Kazakhstan Republic. In this regard, in our opinion, in order to prevent the imperfections of the existing criminal law provisions of the new criminal code, it is part of the first article, which includes responsibility for the secret plunder of the new criminal law (c.188 of the Criminal Code of the Republic of Kazakhstan from 03.07.2014 y.), be as follows:

"Clause 188. Theft

1. Theft, that is the secret plunder of another's property or the acquisition of rights - ".

The proposed revision, in our opinion, have a positive effect on the objectivity of the investigation of criminal cases in this category, and provide the proper legal assessment of the actions of criminals.

\section{Conclusions}

Despite the fact that the application of the criminal law by analogy is not allowed, that derives from the provisions of the Constitution (the Constitution of the Republic of Kazakhstan, 1995), as an example, I would like to bring the provisions of item 22 of the standard decision of the Supreme Court of the Republic of Kazakhstan "on judicial practice in cases of embezzlement" which States that "If the victim did not realize the fact of illegal appropriation of the property in the condition of drunkenness or sleeping, coming as a result of voluntary consumption of alcoholic beverages, drug, virulent, poisonous or stupefying substances, the perpetrator should be classified as secret the embezzlement". In this case, we see that if the property owner was not aware of the wrongfulness of withdrawal, he owns the right of property, the subject of crime, or imply that the theft took place in secret from him the legislator allows such actions qualify as secret plunder, i.e. theft. Why with the same attitude not to approach the solution of problems related to secret illegal acquisition of the right to property and not to qualify these actions under clause 175 of the Criminal Code of the Republic of Kazakhstan. However, the study of criminal cases has shown that in practice when considering the crimes related to the illegal disposal of ownership of dwellings, particularly apartments, law enforcement officers (Internal Affairs agencies, prosecutors, and others.) qualify action under clause 177 of the Criminal Code of the Republic of Kazakhstan.

\section{References}

Archive of Kazybek District Court of Karaganda city (2010a). Criminal case \# 08351303100840.

Archive of Kazybek District Court of Karaganda city (2010b). Criminal case \# 09351003100074.

Archive of Kazybek District Court of Karaganda city (2010c). Criminal case \# 10351003100126.

Arendarenko, A. V., \& Golubov, I. I. (2002). Differentiation of criminal and civil liability for fraud or breach of trust. Lawyer, 4(58). Retrieved from http:/jurist.by/

Begaliyev, B. A. (2009). Challenges of combating fraud: Monograph. Almaty: Dyke-Press.

Borchashvili, I. Sh., \& Mukhashev, A. K. (2009). Crime against property: Monograph. Astana: Institute of Law. 
Borzenkov, G. N. (1971). Liability for fraud. Moscow: Legal Literature.

Commentary on the Criminal Code of the RSFSR. (1971). Moscow: Legal Literature.

Constitution of the Republic of Kazakhstan dated 30 August 1995. Retrieved from http://www.constitution.kz/

Grishaev, P. I. (1967). Soviet criminal law - the right of a new type. Moscow: Law.

Isaev, M. M. (1938). Property crimes. Moscow: Publishing House of the USSR.

Kolesov, I. V. (1992). Forms of causing property damage. Social prevention and legal assessment of the criminal conduct. Perm: Lawyer.

Kuznetsova, I. M. (2002). Course of criminal law. Tome \# 3. Moscow: The Zercalo.

Normative Resolution of the Supreme Court of the Republic of Kazakhstan \# 8. (2003, July 11). On judicial practice in cases of theft. Retrieved from http://online.zakon.kz/Document/

Ozhegov, S. I. (1990). Russian Dictionary (22nd ed.). Moscow: Russian language.

Petukhov, B. V. (2004). On the concept of fraud. Lawyer, 3(63). Retrieved http://jurist.by/

Vladimirov, V. A., \& Lyapunova, Yu. I. (1983). Mercenary attacks on socialist property. M: Legal Literature.

Volzhenkin, B. V. (1998). Series "modern standards in criminal law and procedure." Fraud, (36). St. Petersburg: Law School of the Prosecutor General of the Russian Federation; Isaev M. M. (1938). Property crimes. Moscow: Publishing House of the USSR.

Yakubovich, M. I. (1962). Crimes against socialist property. Moscow: Publishing House of the RSFSR.

\section{Copyrights}

Copyright for this article is retained by the author(s), with first publication rights granted to the journal.

This is an open-access article distributed under the terms and conditions of the Creative Commons Attribution license (http://creativecommons.org/licenses/by/3.0/). 